Anna I. Mantarova ${ }^{1}$

Bulgarian Academy of Sciences, Institute of Philosophy and Sociology

Sofia (Bulgaria)
316.644:314.15(497.2)"2017/2019"

327.56:314.15(497.2)"201"

Original scientific paper

Submitted 13/01/2021

Accepted 25/02/2021

doi: 10.5937/socpreg55-30302

\title{
FORMATION AND DYNAMICS OF ATTITUDES TOWARDS REFUGEES IN BULGARIA ${ }^{2}$
}

\begin{abstract}
The wave of refugees to Europe after 2011 brought tens of thousands of immigrants to Bulgaria, and the society faced unexpected challenges. The aim of the present study is to establish what the attitudes of Bulgarians to refugees are like, what influences these attitudes, whether and how they change over time. The study is based on information collected in surveys in 2017 and 2019 and survey in areas with refugee accommodation centres. New in the article is that it not only reveals the attitudes and identifies their dependencies, but also traces the dynamics over time. The conclusion is that over time the sense of threat subsides and in the formation of the attitude to refugees more and more importance is given to social qualities, and not so much to religious, racial and ethnic affiliation.
\end{abstract}

Keywords: refugees, attitudes towards refugees, discrimination, value systems

\section{Introduction}

Bulgaria is far from the hot spots on the planet, which generate migration flows of millions. It is not even a final destination, but only a transit corridor that is not on the main routes to Western Europe at that. Although it did not face such migratory pressure as other neighbouring countries, Bulgaria was also significantly affected by the so-called wave of refugees. ${ }^{3}$ From 01.01.2011 to 31.12.2019, a total of 68,699 applications for protection were filed in Bulgaria. Refugee status was granted to 12,147 people, and 7,547 people

1 anna.mantarova@abv.bg

2 The study is done in the framework of the project "Social Environment and Deviations: Sustainable Correlations and Situational Influences. Social Deviations in the Context of Contemporary Migration Processes" - Contract DN 05-12/15.12.2016.

${ }^{3}$ Since 2011 - the beginning of the mass arrival in Europe of immigrants from the Middle East and Africa, who claimed to be seeking asylum, the term 'refugees' has become popularin the public domain.Although incorrectly used, it was universally accepted to refer to those who massively move to Europe, independently of whether they have the relevant status or at least whether they meet or not the conditions set out in the 1951 Geneva Convention for obtaining it. In fact, only some of the newcomers have been granted refugee status, others have registered applications and are in the process, so legally they are 'asylum seekers'. In the present work, the analysis is focused on third-country 
were granted humanitarian protection. It is obvious that the causes generating numerous migratory flows to Europe will persist and will increase in the context of the economic crisis and deepening inequalities accompanying the COVID-19 pandemic. Therefore, the topic of the attitudes to immigrants/refugees is of particular importance. The present study aims to establish what are the attitudes formed in Bulgarian society to this group, what influences them and whether and how they change over time. ${ }^{4}$

\section{Theoretical framework}

Theoretically, the study is based on existing concepts about the determinants of attitudes to immigrants (refugees as a special case of immigrants). In the specialized literature as factors influencing attitudes are indicated perception of the threat of coming/presence of immigrants in the country; socio-demographic characteristics; experience in cross-cultural contacts.

Threats (expectation of negative consequences related to the arrival and presence of immigrants) are grouped as real (economic) and symbolic (value-related) (Riek et al., 2006; Scheepers et al., 2002; Sniderman et al., 2004; Stephan \& Renfro, 2002; Esses et al., 2001; Quillian, 1995; Sidanius \& Pratto, 1999; Sears \& Henry, 2003).

To characterize the attitudes to refugees through a wide spectrum of questions, information was collected about their views on the commitments of the State with regard to meeting a certain range of their needs, readiness for spatial and social proximity, equality, participation in and approval of activities aimed at refugees.

The potential threats are divided into three groups - in respect of security (personal and of the society), of the economic situation (expectations of the financial situation of the State to deteriorate due to the accommodation and subsistence of refugees, of redirecting funds earmarked for other purposes, of newcomers to occupy the jobs of the locals and reduction of the cost of labour) and for the national identity (to disturb the ethnic balance in the future, to endanger the national culture and to endanger religious practices and beliefs).

Along the basic socio-demographic characteristics, we assumed a hypothesis that a wider range of personal characteristics will have an impact and we included questions related to the value systems, with a special emphasis on the importance of fundamental EU values that are relevant to the topic of immigrants and refugees.

As for the experience in cross-cultural contacts as a determinant of prejudice and the perception of symbolic threats and attitudes against immigrants (Petigrew \& Tropp, 2011; McLaren, 2003), since there is no significant number of immigrants in Bulgaria, the questions used in other countries regarding contacts with immigrants, here they cannot be expected to be useful for establishing dependence (only $10.6 \%$ in 2017 and $11.7 \%$ in 2019 had contacts).

nationals who have entered Bulgaria without the relevant documents and who have registered applications for protection, and along with the term 'immigrants' the popular term 'refugees' is also used.

${ }^{4}$ The present analysis is based on information collected in PAPI surveys. They were conducted in 2017 and 2019, representative of the country's population over 18 years of age. The sample was stratified probability sample (according to NUTS 2 by size of the locality) with a volume of 840 units and weighting by sex and age. Statistical error within $50 \%= \pm 3.5 \%$. In 2017 , in each of the two towns with accommodation centres - Harmanli and Vrazhdebna - 200 individuals were interviewed according to the same methodology. Statistical error within $50 \%= \pm 6.9 \%$. 
Given the national specifics and the fact that our interest is focused on the attitudes to the now coming immigrants from the Middle East (who are mostly Muslims), in the survey we focused on looking for slightly different but relevant information - the presence and respectively reflection of contacts with locals practicing Islam - contacts that are objectively possible and inevitable in localities with significant presence of Muslim population. Therefore, we collected information on the religions prevalent in the respondents' locality and the homogeneity/heterogeneity in this respect.

\section{Results and comment}

In order to establish the positions regarding the State's commitments to immigrants, in the survey a set of services that meet human needs with different degree of importance was proposed for assessment Fig. 1]. The survey showed that despite the poor economic situation of a large part of the population (according to self-assessments it is poor in $24.7 \%$ of respondents), between three quarters and four fifths were in favour of the State to provide refugees with meeting their basic needs - shelter, food, medical care. The share of positive answers decreases dramatically when it came to the provision of additional services language training, education, work, although they are very important for adaptation and integration in the host society.

In 2017, the opinion that refugees should live in closed centres $-74.2 \%$ clearly dominated. Two years later, however, a significant change was noticed - less than half of the respondents held this position Fig. 2]. In 2017, the disagreement with spatial proximity was strongly expressed. $79.3 \%$ were against refugees settling in the community (neighbourhood), and $83.7 \%$ were against having an accommodation centre in the vicinity. Two years later, there was a very tangible change on this issue as well - the share of respondents who gave the above answers dropped to $70.9 \%$.

The surveys reveal discriminatory attitudes to immigrants in relation to jobs and access to social assistance. Only half of the respondents are for equality of labour rights, and even less - 38.3\% - in the areas with centres. The survey from 2019 provides a more differentiated picture, referring to various components of employment relationships (Fig. 3.

It should be added that $21.5 \%$ of the respondents expressed the opinion that if they were employers and needed workers, they would also hire foreigners for whom they were not sure that they had a work permit. Moreover, this answer was given much more often by categories that are likely to be employers - farmers, private entrepreneurs, skilled workers/technicians. This means that there is a real possibility for discriminatory attitudes to be expressed in discriminatory practices. Regarding the rights to receive social benefits, only $50.3 \%$ of the respondents were in favour of these rights to be identical to those of Bulgarian nationals. In the areas with refugee centres this share was $37.6 \%$.

The information on participation in activities directly concerning immigrants confirms the expectations that the percentages showing actual participation are higher in the places with centres. The largest participation there was in underwriting against the acceptance of refugees $-11.4 \%$. But almost as much (given the size of the random error) were for supporting activities - collecting various types of aid (9.5\%). For the country as a whole, the amount of participants is symbolic. Regarding the expressed approval for certain activities related to the presence of refugees [Fig. 4, the differences between the two 
groups are significantly reduced, and in terms of supporting activities (aid collection and voluntary work) the positive answers in the national sample are more than those in places with centres.

The 2017 survey indicated that the local population definitely associates the presence of refugees with the risk of adverse consequences Fig. 5 - risk of import of terrorism (84.4\%), risk of an increase in various types of crime(66.2\%), disease (74.1\%); a burden for the Bulgarian society (by 83.4\%), negative impact on the labour market (50.2\%). Although not a problem of today, more than two-thirds of people point to another risk a threat to ethnic balance and national identity. It is interesting that in this respect, people in the country are much more concerned than those in places with centres.

The survey of 2019 outlined a certain change and some reassurance. The most serious threat was the financial burden that will be borne by the social system - it was indicated by $79.3 \%$ of respondents. According to $48.8 \%$, the cost of labour would decrease. Now significantly fewer people see a threat to jobs $-42.2 \%$. There is a very serious decrease in the fear of import of terrorism - here the decline was about 20 points - from $84.4 \%$ to $65.7 \%$. The share of people who see immigrants as a threat to the personal security of the local population remained at $66.1 \%$. There was a decrease in the share of people who say that immigrants bring diseases - from $74.1 \%$ to $67.8 \%$. The most significant was the decrease in the number of respondents, who believe that immigrants would endanger our national culture - from $74.9 \%$ they fell to $42.4 \%$, which is probably largely due to the observation that they do not stay in the country.

\section{Determinants of attitudes}

Surprisingly, respondents who say that the State should provide refugees with shelter, food and medical care among those who fully agree with the statements that the latter are an excessive financial burden, that they pose a threat of terrorism, diseases, etc., are by ten or more percentage points more than among those who rather disagree with these statements (Table 1. Obviously, fundamental universal values in this case are determining, and the fear and awareness of the spending of financial resources recede into the background. However, when it comes to the provision of additional services (Table 2) not only the share of positive responses decreased dramatically, but also the relationship with the perception of threats was quite pronounced. The percentage differences reached 20-30 and more percentage points at Cramer's V between 0.190-0.320.

It was established that from personal characteristics, value systems influence this aspect of attitudes, in particular the importance attached to values such as ethnic and religious tolerance, solidarity, equality of different cultures, human equality (Table 3.

And while there were no particularly significant differences for the provision of basic services (and they were completely absent in the case of medical care), regarding the provision of additional ones, the differences were quite noticeable (Cramer between 0.311 and 0.210). Accordingly, the differences between those who gave one or another answer were of the order of tens of points.

When it comes to spatial proximity/distance from refugees, as the strongest determining factors primarily stand perceptions of threats Table 4] and in particular, security threats. The values of the Cramer's (V) show the strongest relation with the perception of 
threat of immigrants to commit crimes against local residents $(\mathrm{V}=0.363)$. As for other types of the defined as material threats - those related to the entry of immigrants into the labour market and the necessary financial means for their support, the dependence is weaker. The impact of symbolic threats is quite pronounced. Respondents, who fully agree with the statement that the settlement of immigrants in the future will disturb the ethnic balance, agree immigrants to settle in their localities/neighbourhoods much less than the average level (9.1\% at $20.6 \%$ national average and $52.6 \%$ of respondents who do not share this opinion).

From the socio-demographic characteristics, our data show a significant influence of the religious affiliation $(\mathrm{V}=0.253)$, education $(\mathrm{V}=0.207)$, financial situation $(\mathrm{V}=0.191)$. As expected, Muslims are twice as likely (47.8\%) to agree to coexist with immigrants. People with higher education (33.3\%) and those in the age group between 30 and 50 are also more prone to neighbourhood.

The acceptance of fundamental EU values such as ethnic and religious tolerance $(\mathrm{V}=0.386)$, equality of different cultures $(\mathrm{V}=0.210)$, solidarity and free movement of people, goods and capital $(\mathrm{V}=0.168)$ also has its impact Fig. 6, Fig. 7). Among persons for whom tolerance is insignificant, the share of those who responded that refugees should live in closed centres was $88.3 \%$, while among those for whom it is very important, it was significantly lower $-55.2 \%$. Conversely, for the accommodation of immigrants in housing at external addresses were respectively $4.9 \%$ and $18.4 \%$.

As for the reluctance regarding immigrant children studying together with children from the local population, the biggest differences were found in connection with the perception of a symbolic threat, namely that the settling of immigrants in the future will disturb the ethnic balance $(\mathrm{V}=0.355)$. Among those who fully agree with this, $77.7 \%$ were supporters of education in separate classes. Security threats also shows quite strong impact. First, the fear that immigrants will commit crimes against locals $(\mathrm{V}=0.346)$. Of those who fully support this statement, $79.2 \%$ were in favour of separating the children of immigrants in separate classes, while only $44.0 \%$ of those who do not accept it held this position. Although less pronounced, there is a relationship with other aspects of the security threat - participation of immigrants in organized crime $(\mathrm{V}=0.246)$, import of terrorism $(\mathrm{V}=0.134)$. In this case, a significant influence of the perception of purely economic threats is also observed ( $\mathrm{V}$ between 0.233 and 0.217 ).

From the socio-demographic characteristics, influence was established of education $(\mathrm{V}=0.272)$, place of residence $(\mathrm{V}=0.212)$, religion $(\mathrm{V}=0.187)$, age $(\mathrm{V}=0.157)$. In summary, the strongest supporters of isolation are persons with primary and secondary education, residents of regional cities, surprisingly - atheists and the youngest (18-29 years old). On the contrary, for joint education are mostly university graduates, people living in Sofia, Muslims and people between 30-39 years old. Interestingly, such a situation-relevant value as human equality is not related to the opinion of where immigrant children should study.

As for the experience of intercultural communication, those living in localities with almost entirely Christian population were the most discriminatory - $63 \%$ of them do not want children of immigrants to study with local children. The opposite position - coed school ( $42.1 \%$ nation average) - much more often were held by persons living in localities where the two main religions in the country are distributed almost equally (47.0\%) and in those where Islam dominates $(47.4 \%)$. 
Interestingly, the biggest differences in terms of equality in the field of labour are observed in connection with the assessment of security risks - crime, import of terrorism, disease transmission. Among the perceptions of threats, the dependence on the claim that immigrants take local jobs and the support for equality in labour rights is very low. This leads to the assumption that the negative attitude to equality on the labour market is not a rational conclusion from specific assessments, but is a product of rejection and fear of a more general nature.

Discriminatory attitudes demonstrate consistency with a number of socio-demographic characteristics. Most often they are expressed by young people between 18 and 29 years of age (56.5\% are against the provision of equal rights to employment) and adults over 60 years old (57.6\%). They are also very common among the less educated - those with primary and basic education (57.7\% and 69.2\%, respectively). Surprisingly (given the higher level of education), only $43.4 \%$ of the capital's residents are in favour of equal labour rights. There are significant differences depending on the ethnicity. Unlike the Turkish $(77.8 \%$ are for equal labour rights), only $42.9 \%$ of the Roma hold this position. Probably in the face of newcomers (who are generally less educated) they see competitors for the jobs available to them. The survey indicated a significant relationship with the financial situation of the respondents $(\mathrm{V}=0.279)$. While people with very good and good economic well-being were for equality (69.4\% and $69.1 \%$ respectively), those with satisfactory and poor status definitely expressed discriminatory attitudes - only $46.2 \%$ of the former and $35.3 \%$ of the latter were in favour of equality. The influence of life satisfaction in general is similar. With its decrease, the share of supporters of equality declines $-72.1 \%, 61.5 \%, 48.5 \%$ and $26.7 \%$, respectively.

As for the impact of values, it was quite clearly expressed in ethnic and religious tolerance $(\mathrm{V}=0.321)$, equality between different cultures $(\mathrm{V}=0.300)$ and solidarity $(\mathrm{V}=0.214)$ (Fig. 8).

As for other aspects of attitudes, the most intolerant are residents of localities with almost entirely Christian population (35.7\% were in favour of equal labour rights), which supports the argument of the positive impact of intercultural contacts and communication.

Logically, the assessment of the financial burden for the country correlates significantly with the position on the issue of equality in the use of social benefits ( $\mathrm{V}=0.273$ ), but it also lags behind other factors - tolerance $(\mathrm{V}=0.299)$, with the fear of disease transmission $(\mathrm{V}=0.291)$.

The two end-point age groups are the most reserved, giving approximately $41 \%$ positive answers. In terms of educational level, the most pronounced discriminatory attitudes showed persons with primary education $(67.3 \%$ were against equal treatment), while among those with higher education two thirds were for equality. Residents of the capital are quite reserved also in this regard - only $39.1 \%$ gave a positive response. Not surprisingly, the Roma, who are the main recipients of social benefits, are largely against the equal treatment of foreigners - 58.8\%. Probably they see them as competitors for the distribution of state resources, a significant part of which by now has been for them, and therefore demonstrate a negative attitude. The same explanation is valid for the relationship with the self-assessment of the financial situation $(\mathrm{V}=0.254)$. As it worsens, the positive responses decrease significantly - they were respectively $67.3 \%$ for people in very good financial status, $65.1 \%$ - in good, $46.7 \%$ - in satisfactory and $33.3 \%$ - in poor. 
The acceptance of fundamental EU values, such as ethnic and religious tolerance $(\mathrm{V}=0.386)$, equality of different cultures $(\mathrm{V}=0.210)$, solidarity and free movement of people, goods and capital $(\mathrm{V}=0.168)$, also has its significant impact Fig. 9.

And in this case, the population of localities with mixed population is more tolerant, especially where there is parity between religious communities $-71.4 \%$ were for equality.

Significant differences depending on the value systems are also observed in the approval of actions that are in aid of or against immigrants (Table 5. The information indicates that regarding approval of actions in support of immigrants, the relationship with ethnic and religious tolerance is the strongest. Almost half of the respondents for whom it is very important, support the gathering of relief, and more than one third - the involvement in voluntary activities for their aid. Conversely, those for whom this value is not particularly important give such answers about six times less often. Secondly, the impact of solidarity comes up. For the actions aimed at non-admission of immigrants to the country, the dependence, although not so strong, on the equality between different cultures could be seen and right next-with ethnic and religious tolerance. These findings lead to a conclusion about the motivating role of perception, evaluation and position in relation to cultural (respectively religious) differences.

It is important to say that according to the survey, devotion to Bulgaria is not associated with negative attitudes towards refugees, but on the contrary - in parallel with it increases tolerance in its various dimensions and acceptance of the other. It was confirmed, although in a slightly different version, the finding of St. Stamenova that "the stronger the respondents' attachment to their own Bulgarian ethnic group, the more they are prone to social tolerance towards the ethnic minorities in the country" (Stamenova, 2019).

\section{Conclusions}

Initially, attitudes towards refugees were formed mainly under the influence of perceptions of the threats that accompany the arrival and presence of such a large number of people, carriers of another culture and religion, under the influence of fear of the unknown. They were characterized by a significant dose of rejection, desire for isolation, distance and discriminatory treatment. However, it is essential that even in this situation of uncertainty about the future course of events universal values prevail and determine support for existential State aid for refugees. Over time, the feeling of threat weakened in society, some reassurance occurred, and in general, in the formation of attitude towards refugees, more and more importance was given to their social qualities, and not so much to their religious and ethnic affiliation. In this situation, value systems acquire key importance and they are the element that must be emphasized in order to create a favourable environment that will motivate immigrants to settle, adapt, develop and participate in Bulgarian society, and from a problem to become a resource for development. 
Ана И. Мантарова ${ }^{1}$

Бугарска академија наука,

Институт за филозофију и социологију

Софија (Бугарска)

\title{
ФОРМИРАЬЕ И ДИНАМИКА СТАВОВА О ИЗБЕГЛИЦАМА У БУГАРСКОЈ ${ }^{2}$
}

\author{
(Превоg In Extenso)
}

Сажетак: У таласу избеглица који је захватио Европу после 2011. године, у Бугарску је дошло на десетине хиљада миграната, због чега се друштво суочило са неочекиваним изазовима. Циљ ове студије јесте да утврди какве ставове Бугари имају према избеглицама, шта утиче на ове ставове, да ли и како се мењају с временом. Студија је заснована на подацима сакупљеним у анкетама из 2017. и 2019. и анкетама из подручја са центрима за смештај избеглица. Новина у овом раду јесте то што он не само открива ставове и препознаје њихову узајамну зависност, већ и то што такође прати динамику током времена. Закључак је да се с временом смисао претње смањује, те да се у формирању става према избеглицама све већи значај придаје друштвеним квалитетима уместо верској, расној или етничкој припадности.

Кључне речи: избеглице, ставови према избеглицама, дискриминација, системи вредности.

\section{Увод}

Бугарска је далеко од жаришта на планети из којих крећу милионски миграциони токови. При томе, Бугарска није чак ни коначно одредиште, већ само транзитни коридор који се не налази на главним путевима ка Западној Европи. Иако се није суочила са миграционим притиском као друге земље у суседству, Бугарска је такође у знатној мери захваћена такозваним таласом избеглица. ${ }^{3}$ Од 1. 1. 2011. до

1 anna.mantarova@abv.bg

2 Студија је рађена у оквиру пројекта „Друштвено окружење и одступања: одрживи корелације и ситуациони утицаји. Друштвена одступања у контексту савремених миграционих процеса “- Уговор DN 05-12 / 15. 12. 2016.

3 Од 2011. године - почетка масовног доласка миграната са Блиског истока и из Африке у Европу, који су тврдили да траже азил, термин избеглице постао је популаран у јавности. Иако се неправилно користи, тај термин је општеприхваћен и означава оне који су се у великом броју доселили у Европу, без обзира на то да ли имају релевантан статус или да ли бар испуњавају услове за добијање тог статуса наведене у Женевској конвенцији из 1951. године. У ствари, само појединим придошлицама је додељен избеглички статус, док су остали поднели пријаве и поступак је у току, па су они са законског становишта азиланти. 
31. 12. 2019. године у Бугарској је поднето укупно 68.699 пријава за заштиту избеглица. Избеглички статус добило је 12.147 лица, док је 7.547 лица добило хуманитарну заштиту. Очигледно је да ће и даље бити разлога за масовне миграционе токове ка Европи и да ће се ти токови повећавати у контексту економске кризе и све израженијих неједнакости које прате пандемију COVID-19. Због тога су ставови према мигрантима/избеглицама тема од посебног значаја. Ова студија има за циљ да утврди какви се ставови према овој групи формирају у бугарском друштву, шта утиче на њих и да ли и како се они с временом мењају.

\section{Теоријски оквир}

Теоријски гледано, ова студија је заснована на постојећим концептима о детерминантама ставова према мигрантима (и избеглицама као посебном групом миграната). У стручној литератури, као фактори који утичу на ставове наводе се перцепција претње од доласка/присуства миграната у земљи; социо-демографске карактеристике; искуство у међукултурним контактима.

Претње (очекиване негативне последице у вези са доласком и присуством миграната) се категоризују као стварне (економске) и симболичне (везано за вредност) (Riek et al., 2006; Scheepers et al., 2002; Sniderman et al., 2004; Stephan \& Renfro, 2002; Esses et al., 2001; Quillian, 1995; Sidanius \& Pratto, 1999; Sears \& Henry, 2003).

Да би се ставови према избеглицама окарактерисали кроз широк спектар питања, сакупљене су информације о њиховим погледима о обавезама државе у смислу испуњавања одређеног обима потреба избеглица, прихватања просторне и друштвене близине, о једнакости, учешћу у активностима усмереним на избеглице и њиховом одобравању.

Потенцијалне претње подељене су у три групе - у погледу безбедности (личне и друштвене), економске ситуације (очекивања да ће се финансијска ситуација у земљи погоршати због смештаја и издржавања избеглица, због преусмеравања средстава намењених за друге сврхе, због тога што ће придошлице преотети послове локалном становништву и због смањења цене рада) и националног идентитета (да ће се у будућности пореметити етничка равнотежа, да ће се угрозити национална култура, верске праксе и убеђења).

Поред основних социо-демографских карактеристика, претпоставили смо да ће утицај имати и шири обим личних карактеристика, па смо укључили питања о системима вредности, с посебним нагласком на значају основних вредности ЕУ које су релевантне за тему о мигрантима и избеглицама.

Анализа у овом раду усредсређена је на држављане земаља трећег света који су ушли у Бугарску без релевантних докумената и који су поднели пријаве за заштиту, а поред термина мигранти користи се и популарни термин избеглице.

${ }^{4}$ Ова анализа заснована је на подацима сакупљеним у традиционалним анкетама помоћу оловке и папира. Спроведене су 2017. и 2019. године, а репрезентативне су за бугарско становништво старије од 18 година. Узорак је стратификовани узорак вероватноће (према NUTS 2 по величини локалитета) са укупно 840 јединица и пондерисањем према полу и годинама старости. Статистичка грешка била је у оквиру $50 \%= \pm 3.5 \%$. Године 2017 . у оба града са прихватним центрима - Харманлију и Враждебни - интервјуисано је 200 лица помоћу исте методологије. Статистичка грешка била је у оквиру $50 \%= \pm 6.9 \%$. 
Што се тиче искуства у међукултурним контактима као детерминанти предрасуда и перцепције симболичких претњи и ставова против миграната (Petigrew \& Tropp, 2011; McLaren, 2003), пошто у Бугарској нема много миграната, не може се очекивати да ће питања која су у другим земљама постављена о контактима са мигрантима овде бити корисна за утврђивање статистичких зависности (контакте је имало само 10,6\% у 2017. и 11,7\% у 2019. години). С обзиром на националне специфичности и чињеницу да су у фокусу нашег интересовања ставови према мигрантима пристиглим са Блиског истока (претежно муслиманске вере), у анкети смо се усредсредили на тражење донекле различитих, али релевантних информација присуство и, самим тим, одраз контаката са мештанима исламске вере - контакти који су објективно могући и неизбежни на местима са знатним присуством муслиманског становништва. Због тога смо сакупили информације о доминантним религијама на локалитетима испитаника и о хомогености/хетерогености у том погледу.

\section{Резултати и коментар}

Да би се утврдили ставови о обавезама државе према мигрантима, у анкети је за процену предложен низ услуга које испуњавају људске потребе, са различитим степеном значаја (Графикон 1) Анкета је показала да, упркос лошој економској ситуацији великог дела становништва (према самопроцени, 24,7\% испитаника сматра да је сиромашно), између три четвртине и четири петине их се изјаснило у прилог замисли да држава треба да испуни основне потребе избеглица за смештајем, храном и здравственом заштитом. Удео позитивних одговора драстично се смањује када је реч о обезбеђивању додатних услуга - језичких курсева, образовања, посла, иако су они веома важни за адаптацију и интеграцију у друштво земље домаћина.

Године 2017. је 74,2\% испитаника сматрало да избеглице треба да живе у затвореним центрима. Две године касније, међутим, забележена је значајна промена - овакав став имало је мање од половине испитаника (Графикон 2). Године 2017. јасно је изражено неслагање са просторном близином - 79,3\% испитаника било је против тога да се избеглице настане у њиховој заједници (суседству), а 83,7\% било је против прихватних центара за избеглице у близини. Две године касније дошло је до упадљиве промене и у погледу овог питања - удео испитаника који су одговорили као раније опао је на 70,9\%.

Анкете откривају дискриминаторне ставове према мигрантима када је реч о запослењу и доступности социјалне помоћи. Само половина испитаника сагласна је са једнакошћу права на рад, а још мање њих - 38,3\% - подручјима са прихватним центрима. Анкета из 2019. даје издиференцирану слику која се односи на различите компоненте радног односа/запослења (Графикон 3)

Треба додати да је 21,5\% испитаника изразило позитивно мишљење о томе како би, у случају да су послодавци и да су им потребни радници, запослили и странце за које нису сигурни да поседују радну дозволу. Осим тога, овај одговор давале су много чешће категорије које се сматрају послодавцима - земљорадници, приватни предузетници, квалификовани радници/техничари. То значи да постоји стварна могућност за изражавање дискриминаторних ставова у пракси. Када је реч о правима на добијање социјалних бенефиција, свега 50,3\% испитаника изјаснило се да 
би ова права требало да буду иста као и права бугарских држављана. У подручјима са избегличким центрима овај удео износио је $37,6 \%$.

Информације о учешћу у активностима које се директно односе на мигранте потврђују да су очекивани проценти о стварном учешћу виши на местима са центрима за мигранте. Највеће учешће забележено је у неприхватању избеглица - 11,4\%. Међутим, готово исто толико испитаника (узимајући у обзир величину случајне грешке) потврдно се изјаснило за активности подршке - прикупљања разних врста помоћи (9,5\%). За државу у целини, број учесника је симболичан. Када је реч о израженом одобравању неких активности у вези са присуством избеглица (Графикон 4) разлике између две групе знатно су мање, а када је реч о активностима подршке (сакупљање помоћи и добровољни рад), позитивних одговора у националном узорку има више у односу на места са прихватним центрима.

Анкета из 2017. показала је да локално становништво дефинитивно повезује присуство избеглица са ризиком од негативних последица (Графикон 5) - ризиком од тероризма $(84,4 \%)$; ризиком од пораста разних врста криминала $(66,2 \%)$; ризика од болести $(74,1 \%)$; ризика од терета за бугарско друштво $(83,4 \%)$ и негативног утицаја на тржиште рада (50,2\%). Иако то није нов проблем, више од две трећине испитаника указало је на још један ризик - опасност по етничку равнотежу и национални идентитет. Занимљиво је да су у том погледу људи у земљи уопште много забринутији у односу на људе који живе у местима са прихватним центрима.

Анкета из 2019. забележила је извесну промену и побољшање у ставовима. Најозбиљнију претњу представљао је финансијски терет који ће поднети социјални систем - на овај начин изјаснило се 79,3\% испитаника. По мишљењу 48,8\% испитаника, цена рада ће пасти. Сада је знатно мање људи видело опасност по послове њих 42,2\%. Забележено је озбиљно смањење страха када је реч о тероризму - за око 20 процентних поена - са 84,4\% на 65,7\%. Удео људи који виде мигранте као опасност по личну безбедност локалног становништва задржао се на 66,1\%. Смањен је удео људи који сматрају да мигранти преносе болести - са 74,1\% на 67,8\%. Најзначајније смањење забележено је у броју испитаника који верују да ће мигранти угрозити нашу националну културу - тај број се спустио 74,9\% на 42,4\%. Разлог за ово највероватније је запажање да се мигранти неће задржати у земљи.

\section{Детерминанте ставова}

Изненађујуће је то што су испитаници који су за то да држава треба да обезбеди избеглицама смештај, храну и здравствену заштиту за десет или више процентних поена бројнији међу онима који се потпуно слажу са тврдњама да избеглице представљају огроман финансијски терет, терористичку претњу и извор болести него међу онима који се уопште не слажу са овим тврдњама (Табела 1). Очигледно су у овом случају пресудне основне универзалне вредности, док се страх и неслагање са трошењем финансијских средстава повлаче у други план. Међутим, када је реч о пружању додатних услуга (Табела 2), не смањује се драстично само удео позитивних одговора, већ је прилично изражена и статистички значајна веза са перцепцијом претњи. Процентуалне разлике достигле су 20-30 и више процентних поена и вредност Крамеровог V коефицијента између 0,190 и 0,320. 
Утврђено је да на основу личних карактеристика системи вредности утичу на овај аспект ставова, нарочито на значај који се придаје вредностима као што су етничка и верска толеранција, солидарност, једнакост различитих култура и једнакост међу људима (Табела 3)

И док није било упадљивих разлика у погледу пружања основних услуга (при чему су те разлике биле непостојеће у случају здравствене заштите), разлике и коефицијенти асоцијација веома су упадљиви када је реч о пружању додатних услуга (Крамеров V коефицијент између 0,311 и 0,210). Сходно томе, разлике између испитаника који су дали један или други одговор износиле су и на десетине процентних поена.

У погледу просторне близине/удаљености од избеглица, као најснажнији детерминишући фактори истичу се перцепције претњи (Табела 4), а нарочито претњи по безбедност. Вредности Крамеровог V коефицијента показују најјачу везу између перцепције претње да ће мигранти починити злочине против локалног становништва $(\mathrm{V}=0,363)$. Када је реч о осталим врстама претњи, дефинисаних као материјалне односно претње које су повезане са доласком миграната на тржиште рада и неопходним финансијским средствима за њихову подршку, веза је слабија. Веома је изражен утицај симболичних претњи. Испитаници који се потпуно слажу са тврдњом да ће досељавање миграната пореметити етничку равнотежу у будућности, много мање су сагласни са тиме да се мигранти настане у њиховим местима/суседствима него што је то просечан ниво (9,1\% према националном просеку од 20,6\%, док 52,6\% испитаника не дели ово мишљење).

На основу социо-демографских карактеристика успостављена је значајна веза са верском припадношћу ( $\mathrm{V}=0,253)$, образовањем $(\mathrm{V}=0,207)$ и финансијском ситуацијом $(\mathrm{V}=0,191)$. Као што је очекивано, постоји двострука вероватноћа да ће Муслимани прихватити суживот са мигрантима. Особе са вишим степеном образовања $(33,3 \%)$ и оне у старосној групи између 30 и 50 година склоније су да прихвате мигранте у суседству.

Такође се истичу значајне везе са прихватањем основних вредности ЕУ Графикон 6 и Графикон 7), као што су етничка и верска толеранција $(\mathrm{V}=0,386)$, једнакост различитих култура $(\mathrm{V}=0,210)$, солидарност и слободно кретање људи, добара и капитала $(\mathrm{V}=0,168)$. Међу испитаницима којима је толеранција неважна, удео оних који су одговорили да избеглице треба да живе у затвореним центрима био је 88,3\%, док је тај проценат знатно нижи - 55,2\% - међу онима којима је толеранција веома важна. Насупрот томе, у прилог смештаја миграната ван прихватних центара изјаснило се $4,9 \%$, односно $18,4 \%$ испитаника.

Када је реч о онима који се противе да деца миграната похађају школу заједно са децом локалних становника, највеће разлике забележене су у вези са перцепцијом симболичке претње, тј. да ће досељавање миграната пореметити етничку равнотежу у будућности $(\mathrm{V}=0,355)$. Међу онима који се потпуно слажу са тиме, 77,7\% је подржало школовање у одвојеним одељењима. Опасност по безбедност такође показује веома снажне везе. На првом месту је страх да ће мигранти починити злочине против локалног становништва ( $\mathrm{V}=0,346)$. Од испитаника који потпуно подржавају ову тврдњу, $79,2 \%$ се изјаснило у прилог раздвајања деце миграната у одвојена одељења, док свега 44,0\% њих није прихватило овакав став. Иако мање изражена, постоји веза са другим аспектима претње по безбедност, а то су: укљученост миграната у организовани 
криминал $(\mathrm{V}=0,246)$ и тероризам $(\mathrm{V}=0,134)$. У овом случају забележен је и знатан утицај перцепције чисто економске опасности (V између 0,233 и 0,217).

На основу социо-демографских карактеристика утврђен је утицај образовања $(\mathrm{V}=0,272)$, пребивалишта $(\mathrm{V}=0,212)$, вероисповести $(\mathrm{V}=0,187)$ и старосне доби $(\mathrm{V}=0,157)$. Укратко, највећи заговорници изолације миграната су особе са завршеном основном и средњом школом, становништво регионалних градова и, као изненађујуће откриће, атеисти и најмлађе особе (старости између 18 и 29 година). Насупрот томе, у прилог заједничког школовања изјаснили су се углавном испитаници са универзитетском дипломом, становници Софије, Муслимани и они између 30 и 39 година живота. Занимљиво је да једнакост међу људима као вредност релевантна за дату ситуацију уопште није повезана са мишљењем о томе где би деца миграната требало да похађају школу.

Када је реч о искуству у међукултурној комуникацији, људи који живе на локацијама са већинским хришћанским становништвом били су најдискриминаторнији - њих 63\% не жели да деца миграната похађају школу заједно са децом мештана. Супротан став - о заједничком похађању школе (национални просек од $42,1 \%$ ) много чешће су имали испитаници који живе у местима где су две главне вероисповести у земљи готово равномерно распоређене (47,0\%), као и у местима где је ислам доминантан $(47,4 \%)$.

Занимљиво је то што су највеће разлике у једнакости у области рада примећене у вези са проценом ризика по безбедност - криминала, тероризма и преношења болести. Међу перцепцијама претњи, најслабија је зависност између тврдње да мигранти преузимају локалне послове и подржавања једнакости у правима на рад. То доводи до претпоставке да негативан став према једнакости на тржишту рада није рационалан закључак на основу посебних процена, већ производ одбацивања и страха уопштеније природе.

Дискриминаторни ставови показују доследност у односу на бројне социо-демографске карактеристике. Најчешће их изражавају млади између 18 и 29 година живота (56,5\% њих је против давања једнаких права приликом запослења) и одрасли старији од 60 година (57,6\%). Овакви ставови такође су уобичајени међу људима са нижим степеном образовања - са завршеном основном и средњом школом $(57,7 \%$ односно 69,2\%). Изненађујуће је то што се (имајући у виду виши ниво образовања) свега $43,4 \%$ становника главног града изјашњава у прилог једнаких права запослених. Постоје значајне разлике у зависности од етничке припадности. За разлику од Турака (77,8\% се залажу за једнака права запослених), овакав став има само 42,9\% Рома. Суочени са придошлицама (који су уопштено мање образовани), Роми вероватно у њима виде конкуренцију за доступне послове. Ова анкета указала је на значајну везу са финансијском ситуацијом испитаника $(\mathrm{V}=0,279)$. Док се људи веома доброг и доброг економског стања изјашњавају у прилог једнакости (69,4\% односно 69,1\%), они са задовољавајућим и лошим економским статусом дефинитивно су изразили дискриминаторне ставове - у корист једнакости било је само 46,2\% испитаника са задовољавајућим, а 35,3\% оних са лошим економским статусом. Слична је веза и са животним задовољством уопште. Што је ниво животног задовољства нижи, то је и удео заговорника једнакости мањи и износи $72,1 \%, 61,5 \%, 48.5 \%$ односно 26,7\% за наведене групе. 
Када је реч о вези са вредностима, она је сасвим јасно изражена у односу на етничку и верску толеранцију ( $\mathrm{V}=0,321)$, једнакост између различитих култура $(\mathrm{V}=0,300)$ и солидарност $(\mathrm{V}=0,214)$ (Графикон 8).

Када говоримо о осталим аспектима ставова, најнетолерантнији су становници места са готово искључиво хришћанским становништвом (35,7\% их је било за једнака права запослених), што поткрепљује аргумент о позитивном утицају међукултурних контаката и комуникације.

Логично је то што је процена финансијског оптерећења за земљу значајно повезана са ставом о питању једнакости у коришћењу социјалних бенефиција ( $\mathrm{V}=0,273)$, али она такође заостаје у односу на остале везе - толеранцијом $(\mathrm{V}=0,299)$ и страхом од преношења болести $(\mathrm{V}=0,291)$.

Две поменуте старосне групе као крајности су најрезервисаније, са отприлике $41 \%$ позитивних одговора. Када је реч о нивоу образовања, најупадљивије дискриминаторне ставове показале су особе са завршеном основном школом $(67,3 \%$ је било против једнаког третмана), док је међу онима са вишим образовањем њих две трећине било за једнакост. И становници главног града прилично су резервисани у овом погледу - позитиван одговор дало је свега $39,1 \%$. Није чудно што Роми, који су главни примаоци социјалне помоћи, у великој мери против једнаког третмана странаца - 58,8\%. Највероватније у њима виде конкуренцију у расподели државних средстава, чији је знатан део до сада припадао њима, па стога заузимају негативан став. Исто објашњење важи и за везу са самопроценом финансијске ситуације $(\mathrm{V}=0,254)$. Што је финансијска ситуација гора, то је мањи и број позитивних одговора - они су износили 67,3\% за људе са веома добрим финансијским статусом, 65,1\% - за оне са добрим, $46,7 \%$ - са задовољавајућим и $33,3 \%$ - са лошим финансијским статусом.

Такође се истичу везе са прихватањем основних вредности ЕУ (Графикон 9), као што су етничка и верска толеранција $(\mathrm{V}=0,386)$, једнакост различитих култура $(\mathrm{V}=0,210)$, солидарност и слободно кретање људи, добара и капитала $(\mathrm{V}=0,168)$.

У овом случају су толерантнији испитаници у местима са мешовитим становништвом, нарочито тамо где постоји паритет између верских заједница - 71,4\% испитаника било је за једнакост.

Значајне разлике у зависности од система вредности такође су примећене у одобравању активности које су за помоћ или против помоћи мигрантима (Табела 5) Овај податак указује на то да је, када је реч о одобравању активности за подршку мигрантима, најснажнија је веза са етничком и верском толеранцијом. Готово половина испитаника којима је оваква толеранција веома важна подржава сакупљање помоћи, а више од трећине њих подржава учешће у добровољним активностима за помоћ мигрантима. Насупрот томе, они којима ова вредност није нарочито значајна дају такве одговоре отприлике шест пута ређе. Друго, порастао је утицај солидарности. У погледу активности усмерених на спречавање доласка миграната у земљу, може се видети веза, мада не тако снажна, са једнакошћу између различитих култура, и то одмах после етничке и верске толеранције. Ове везе доводе до закључка о мотивишућој улози перцепције, евалуације и става у вези са културним (односно верским) разликама.

Важно је истаћи да, на основу спроведене анкете, оданост Бугарској није повезана са негативним ставовима према избеглицама већ, напротив - паралелно са 
њом повећава се толеранција у својим различитим димензијама и прихватање других. Потврђен је, иако у донекле другачијој верзији, закључак Светлане Стаменове да „што је снажнија приврженост испитаника њиховој властитој бугарској етничкој групи, то су они склонији друштвеној толеранцији према етничким мањинама у земљи" (Stamenova, 2019).

\section{Закључци}

У почетку су се ставови према избеглицама формирали углавном под утицајем перцепција претњи које прате долазак и присуство тако великог броја људи, представника друге културе и религије, а под утицајем страха од непознатог. Ти ставови одликовали су се значајном дозом одбацивања придошлица, жељом за њиховом изолацијом, дистанцом и дискриминаторним понашањем. Међутим, битно је да чак и у оваквој неизвесној ситуацији због будућег тока догађаја преовладавају универзалне вредности и захтеви за егзистенцијалном помоћи државе избеглицама. С временом је осећање угрожености у друштву нестајало, створена су извесна убеђења, а приликом формирања става према избеглицама, уопштено говорећи, све већи значај придаје се њиховим друштвеним квалитетима, а не њиховој верској и етничкој припадности. У таквој ситуацији, системи вредности добијају кључни значај и представљају елементе који се морају нагласити како би се створило повољно окружење које ће мигранте подстаћи да се скрасе, прилагоде, развијају и да учествују у бугарском друштву, те да од проблема постану средство за развој.

\section{REFERENCES/ ЛИTЕРАTУPA:}

Esses, V., Dovidio, J., Jackson, L. and T. Armstrong. (2001). The immigration dilemma: The role of perceived group competition, ethnic prejudice and national identity. Journal of Social Issues 57 (3) 2001, 389-412.

Pettigrew, T. \& Tropp, L. (2011). When groups meet: The dynamics of intergroup contact. Philadelphia, PA: Psychology Press.

Quillian, L. (1995). Prejudice as a response to perceived group threat: Population composition and anti-immigrant and racial prejudice in Europe. American Sociological Review, vol. 60, No. 4.

Riek B., Mania, E. and Gaertner, S. (2006). Intergroup threat and outgroup attitudes: A metaanalytic review. Personality and Social Psychology review, 2006, 10 (4), pp. 336-353.

Scheepers, P., Gijsberts, M. \& Coenders, M.(2002). Ethnic exclusion in European countries. Public opposition to civil rights for legal migrants as a response to perceived ethnic threat. European Sociological Review, 2002, 18, pp. 17-34.

Sears, D. \& Henry, P. (2005). Over thirty years later: A contemporary look at symbolic racism and its critics. In: M. Zanna (Ed.), Advances in Experimental Social Psychology. New York: Academic Press, pp. 95-150.

Sidanius, J., and Pratto, F. (1999). Social Dominance. Cambridge: Cambridge University Press. 
Sniderman, P., Hagendoorn, L. and Prior, M. Predisposing factors and situational triggers: exclusionary reaction to immigrant minorities. American Political Science Review 2004, 98 (1), pp. 35-49.

Stamenova, Sv. (2019). Political and Ethnic Influences on the National Consciousness of the Bulgarian Ethnic Majority. Sofia: Paradigma [In Bulgarian]

Stephan, W., and Renfro. C. (2002). The role of threat in intergroup relations. In: D. Mackie and E. R. Smith (Eds.) From prejudice to intergroup emotions: Differentiated reactions to social groups. New York: Psychology Press, pp. 191-207.

Zorba, H. (2016). Turkish and European Perspectives on Syrian Migration since 2011 (doctoral thesis) Yildirim Beyazit University, Ankara. 


\section{APPENDIX / ПРИЛОГ}

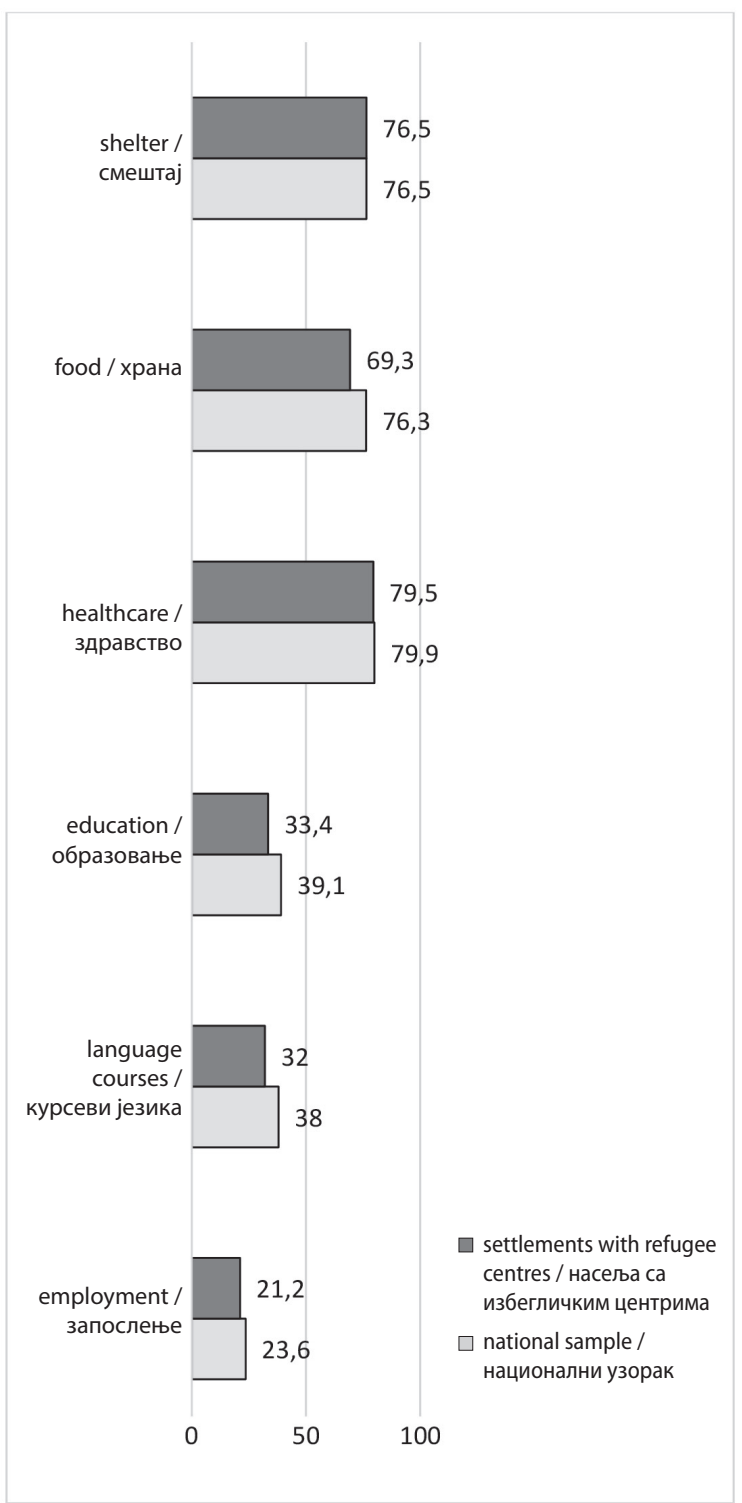

Figure 1. What should the state provide for refugees? / Графикон 1. Шта држава треба да обезбеди избеглицама? 
BACK

НАЗАД

— BACK

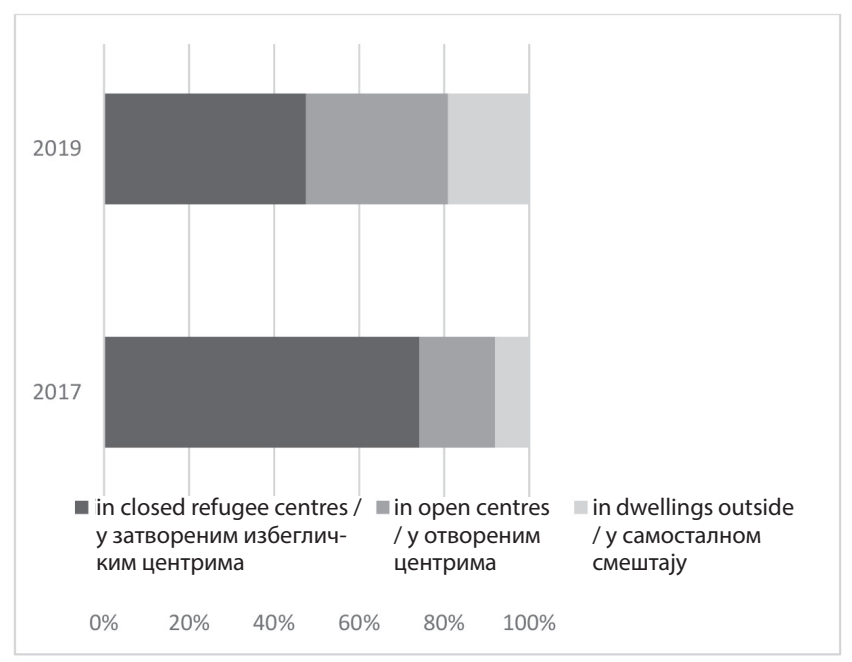

Figure 2. Where should refugees live? / Графикон 2. Где избеглице треба да живе?

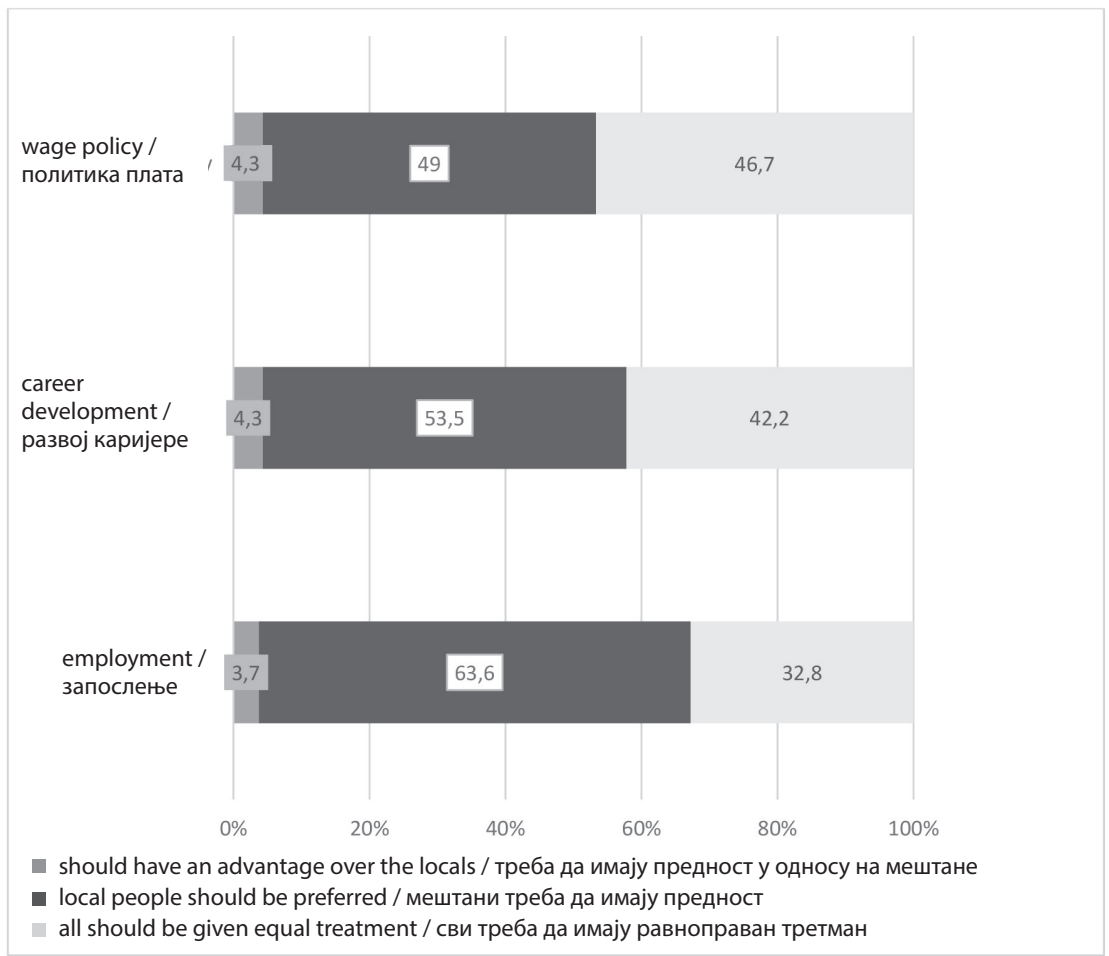

Figure 3. How to deal with immigrants? / Графикон 3. Како поступати са мигрантима? 


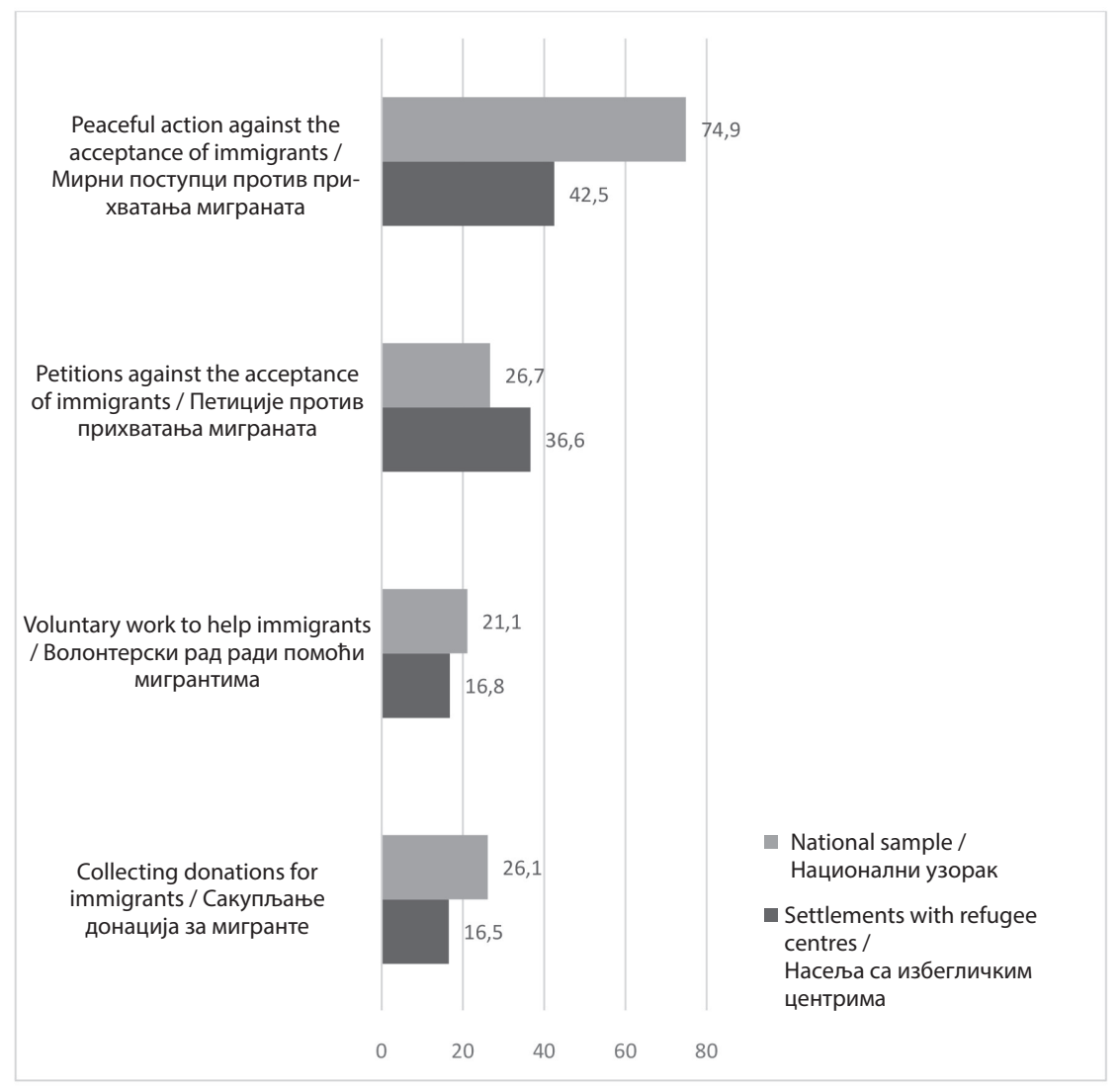

Figure 4. Approval of some actions / Графикон 4. Одобравање одређених поступака 


\section{BACK}

- НАЗАД

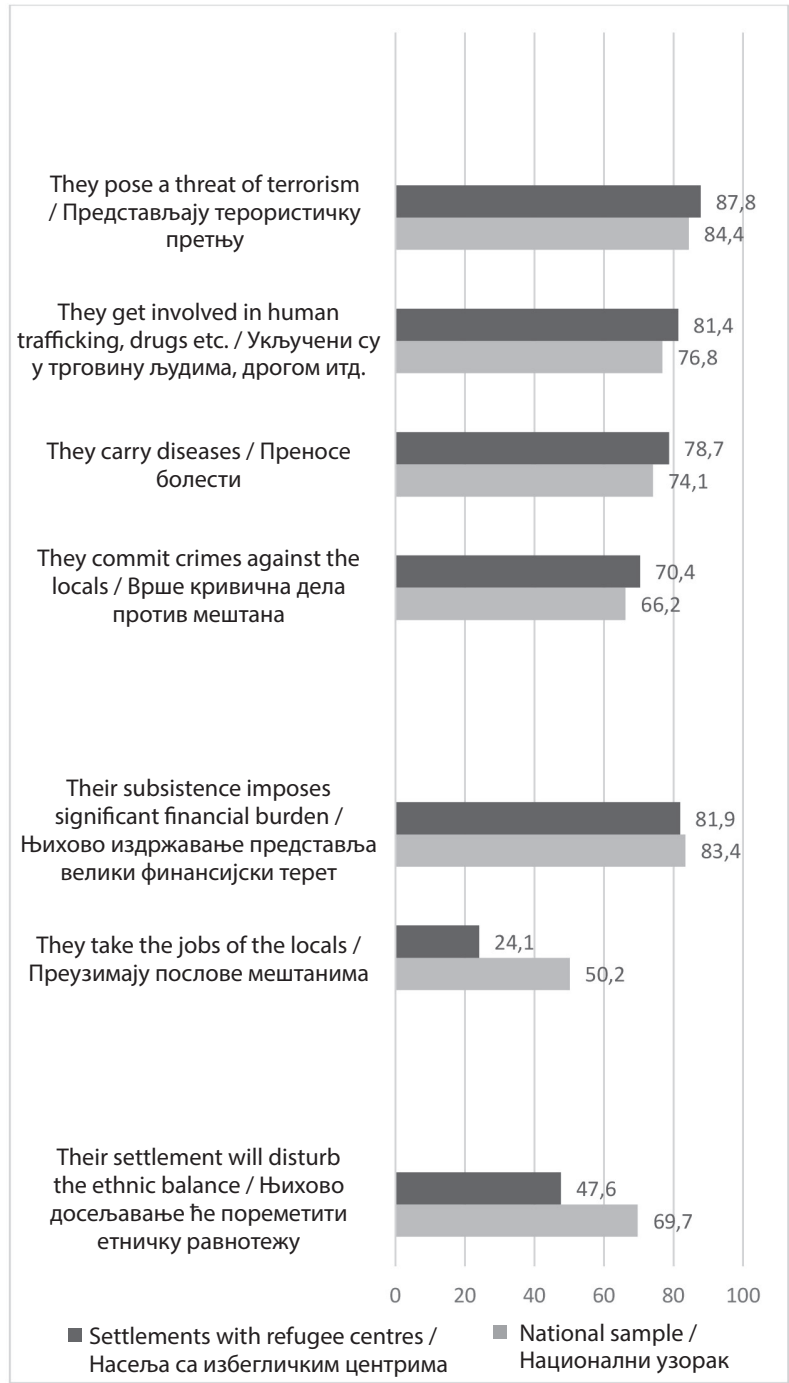

Figure 5. Perceptions of some threats / Графикон 5. Перцепција појединих претњи 
Equality of different cultures is of little importance / Равноправност различитих култура је од малог значаја

Equality of different cultures is very important / Равноправност различитих култура је веома значајна

Ethnic and religious tolerance is of little importance / Етничка и верска толеранција је од малог значаја

Ethnic and religious tolerance is very important / Етничка и верска

толеранција је веома значајна

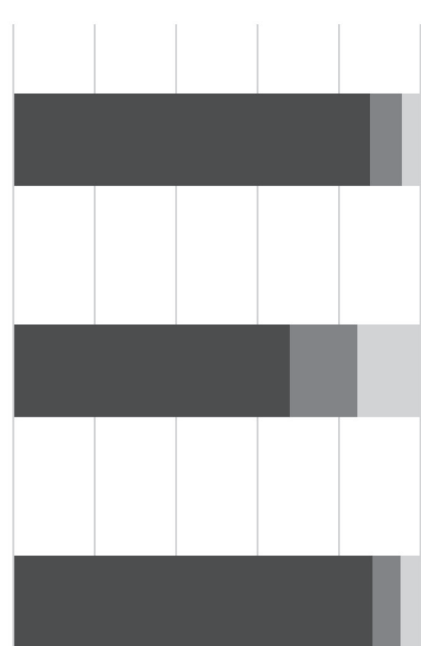

National sample / Национални узорак

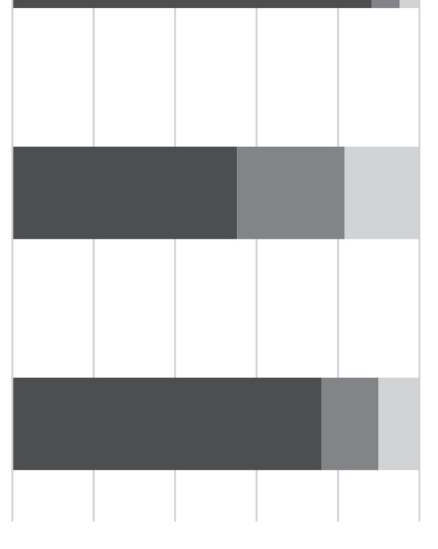

n in closed centres /у затвореним избегличким центрима

\section{- in open centres} / у отвореним центрима

$\square$ in dwellings outside / y самосталном смештају

Figure 6. Opinions where should refugees live and the importance attached to certain values / Графикон 6. Мишљења о томе где избеглице треба да живе и значај који се придаје одређеним вредностима 
Ethnic and religious tolerance / Етничка и верска толеранција

Equality of different cultures / Равноправност различитих култура

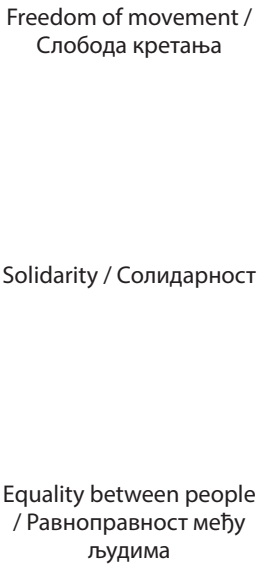

Solidarity / Солидарност

Equality between people / Равноправност међу људима
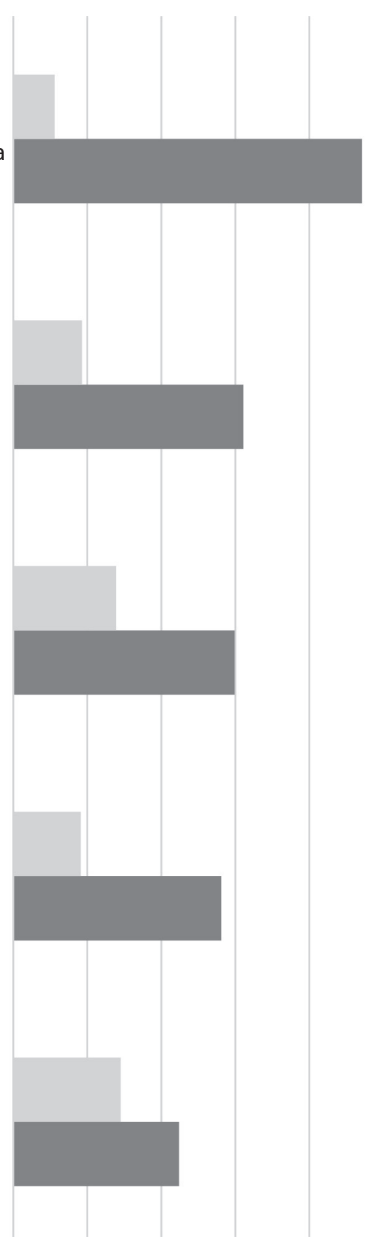

$\begin{array}{llllll}0 & 10 & 20 & 30 & 40 & 50\end{array}$

of little importance / од малог значаја

very important / веома значајно

Figure 7. Consent that refugees settle in the community/neighbourhood and the importance attached to certain values / Графикон 7. Сагласност о томе да избеглице треба да живе у заједници/суседству и значај који се придаје одређеним вредностима 


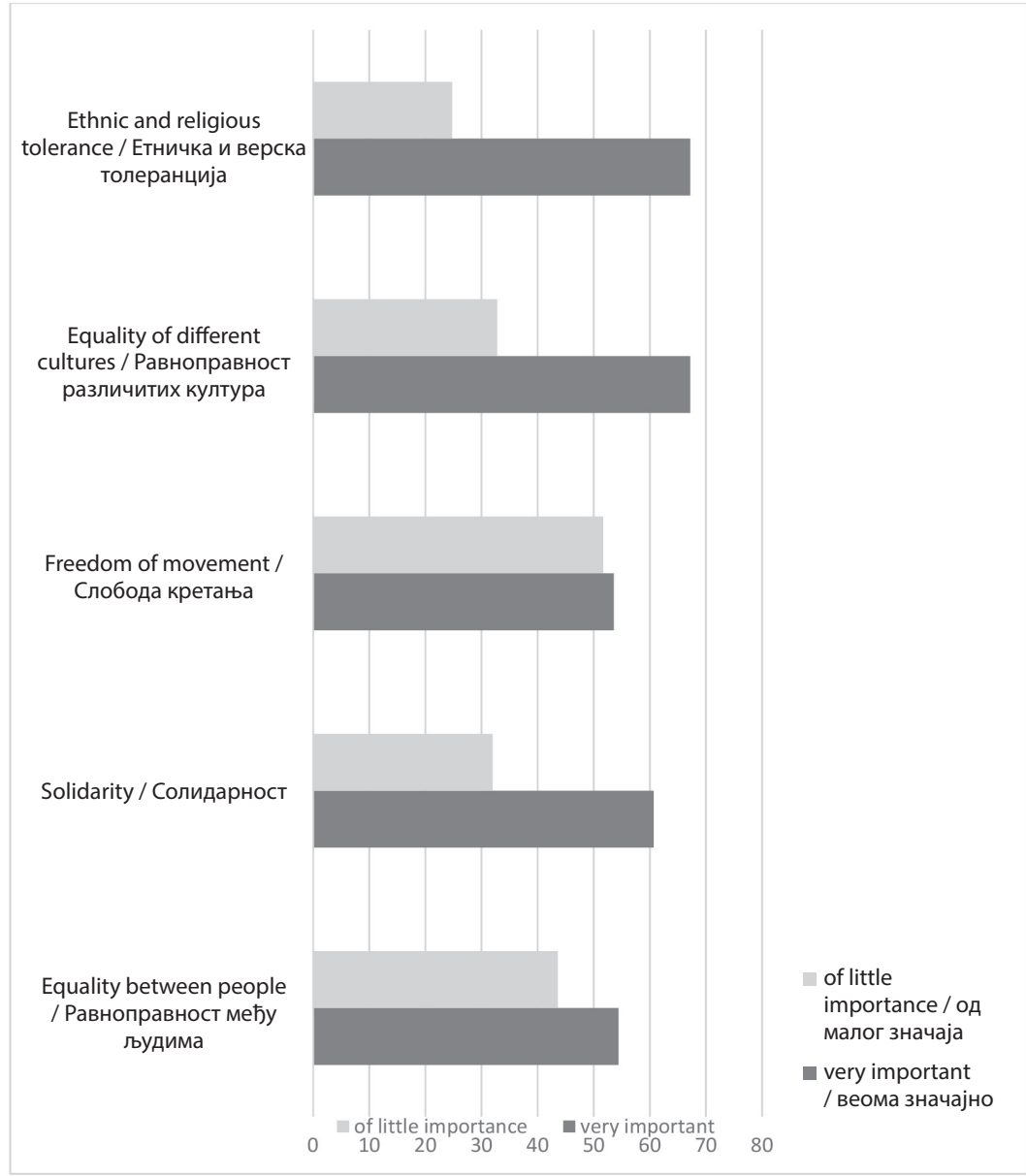

Figure 8. Consent that foreign citizens of countries outside the EUmay have the same rights to employment as Bulgarian citizens and the importance attached to certain values / Графикон 8. Сагласност о томе да страни грађани земаља ван ЕУ могу да имају иста права као грађани Бугарске и значај који се придаје одређеним вредностима 


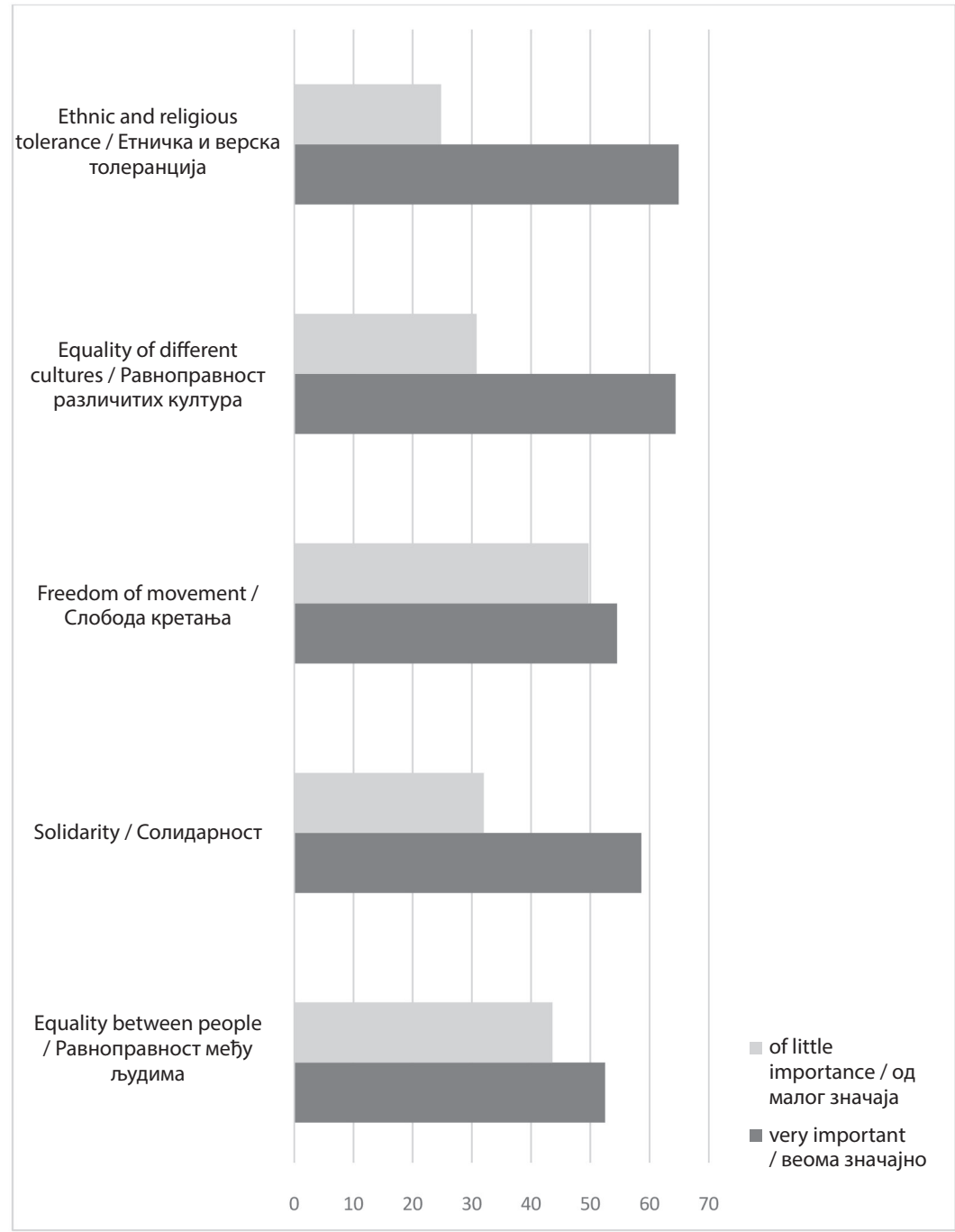

Figure 9. Consent that foreign citizens of countries outside the EU may have the right to receive the same welfare benefits as Bulgarian citizens and the importance attached to certain values / Графикон 9. Сагласност о томе да страни грађани земаља ван ЕУ могу да имају право на исте социјалне бенефиције као грађани Бугарске и значај који се придаје одређеним вредностима 
Table 1. What should the state provide and perceptions of some threats ${ }^{1}$ (in \%) Табела 1. Шта држава треба да обезбеди и перцепције одређених претњи ${ }^{1}$ (у \%)

\begin{tabular}{|c|c|c|c|}
\hline & $\begin{array}{l}\text { Shelter/ } \\
\text { Смештај }\end{array}$ & $\begin{array}{l}\text { Food/ } \\
\text { Храна }\end{array}$ & $\begin{array}{l}\text { Healthcare/ } \\
\text { Здравствена } \\
\text { заштита }\end{array}$ \\
\hline National sample / Национални узорак & 76,5 & 76,3 & 79,9 \\
\hline $\begin{array}{l}\text { Their subsistence imposes significant financ } \\
\text { burden/ Њихово издржавање намеће огром } \\
\text { финансијски терет } \\
\text { fully agree / потпуно се слажем } \\
\text { rather disagree / уопште се не слажем/ }\end{array}$ & $\begin{array}{l}70,2 \\
77,5\end{array}$ & $\begin{array}{l}76,1 \\
72,1\end{array}$ & $\begin{array}{l}83,1 \\
70,2 \\
\end{array}$ \\
\hline $\begin{array}{l}\text { They take the jobs of the locals/ Они одузим } \\
\text { послове локалном становништву } \\
\text { fully agree / потпуно се слажем } \\
\text { rather disagree / уопште се не слажем }\end{array}$ & $\begin{array}{l}70,1 \\
78,\end{array}$ & $\begin{array}{l}70,6 \\
79,4 \\
\end{array}$ & $\begin{array}{l}80,2 \\
80,3\end{array}$ \\
\hline $\begin{array}{l}\text { They pose a threat of terrorism/ Они } \\
\text { представљају терористичку претњу } \\
\text { fully agree / потпуно се слажем } \\
\text { rather disagree / уопште се не слажем }\end{array}$ & $\begin{array}{l}78,6 \\
72,0 \\
\end{array}$ & $\begin{array}{l}77,9 \\
72,6 \\
\end{array}$ & $\begin{array}{l}84,5 \\
70,1 \\
\end{array}$ \\
\hline $\begin{array}{l}\text { They commit crimes against the locals/ } \\
\text { Они врше кривична дела против локалног } \\
\text { становништва } \\
\text { fully agree / потпуно се слажем } \\
\text { rather disagree / уопште се не слажем }\end{array}$ & $\begin{array}{l}69,8 \\
12,8 \\
\end{array}$ & $\begin{array}{l}68,1 \\
76,6 \\
\end{array}$ & $\begin{array}{l}79,7 \\
75,0 \\
\end{array}$ \\
\hline $\begin{array}{l}\text { They carry diseases/ Они преносе болести } \\
\text { fully agree / потпуно се слажем } \\
\text { rather disagree / уопште се не слажем }\end{array}$ & $\begin{array}{l}78,7 \\
76,3\end{array}$ & $\begin{array}{l}76,3 \\
77,5\end{array}$ & $\begin{array}{l}85,2 \\
75,0\end{array}$ \\
\hline $\begin{array}{l}\text { Their settlement will disturb the ethnic bal- } \\
\text { ance/ Њихово досељавање ће пореметити } \\
\text { етничку равнотежу } \\
\text { fully agree / потпуно се слажем } \\
\text { rather disagree / уопште се не слажем }\end{array}$ & $\begin{array}{l}63,9 \\
85,6\end{array}$ & $\begin{array}{l}63,4 \\
85,6\end{array}$ & $\begin{array}{l}72,2 \\
85,6\end{array}$ \\
\hline
\end{tabular}

1 The comparison of variations in attitudes depending on the perception of threats is between the positions "fully agree" and "rather disagree", as the extreme position "totally disagree" is held by a very small number of respondents and its use in search of relationships is not relevant.

1 Поређење варијација у ставовима у зависности од перцепције претњи дато је између ставова „потпуно се слажем” и „уопште се не слажем”, где екстремни став „уопште се не слажем” има веома мали број испитаника, па његова употреба у потрази за везама није релевантна. 
Ана И. Мантарова, Формираюе и динамика сӣавова о избеілицама у Буїарској

Table 2. What should the state provide and perceptions of some threats(in \%)/

Табела 2. Шта држава треба да обезбеди и перцепције одређених претњи (у \%)

\begin{tabular}{|c|c|c|c|}
\hline & $\begin{array}{l}\text { Education/ } \\
\text { Образовање }\end{array}$ & $\begin{array}{l}\text { Language courses } \\
\text { /Курсеви језика }\end{array}$ & $\begin{array}{l}\text { Jobs/ } \\
\text { Послови }\end{array}$ \\
\hline National sample/ Национални узорак & 76,5 & 76,3 & 79, \\
\hline $\begin{array}{l}\text { Their subsistence imposes significant } \\
\text { financial burden / Њихово издржавање } \\
\text { намеће огроман финансијски терет } \\
\text { fully agree / потпуно се слажем } \\
\text { rather disagree / уопште се не слажем }\end{array}$ & $\begin{array}{l}24,5 \\
54,8\end{array}$ & $\begin{array}{l}21,8 \\
55,8\end{array}$ & $\begin{array}{l}12,7 \\
38,8 \\
\end{array}$ \\
\hline $\begin{array}{l}\text { They take the jobs of the locals/ } \\
\text { Они одузимају послове локалном } \\
\text { становништву } \\
\text { fully agree / потпуно се слажем } \\
\text { rather disagree / уопште се не слажем }\end{array}$ & $\begin{array}{l}18,6 \\
42,4 \\
\end{array}$ & $\begin{array}{l}20,3 \\
41,2 \\
\end{array}$ & $\begin{array}{l}14,1 \\
23,9\end{array}$ \\
\hline $\begin{array}{l}\text { They pose a threat of terrorism / Они } \\
\text { представљају терористичку претњу } \\
\text { fully agree / потпуно се слажем } \\
\text { rather disagree / уопште се не слажем }\end{array}$ & $\begin{array}{l}7,7 \\
44,9\end{array}$ & $\begin{array}{l}22,9 \\
56,1\end{array}$ & $\begin{array}{l}13,0 \\
29,0\end{array}$ \\
\hline $\begin{array}{l}\text { They commit crimes against the locals/ } \\
\text { Они врше кривична дела над локалним } \\
\text { становништвом } \\
\text { fully agree / потпуно се слажем } \\
\text { rather disagree / уопште се не слажем }\end{array}$ & \begin{tabular}{|l}
18,5 \\
53,8
\end{tabular} & $\begin{array}{l}16,8 \\
52,5\end{array}$ & $\begin{array}{l}10,8 \\
33,6\end{array}$ \\
\hline $\begin{array}{l}\text { They carry diseases/ Они преносе } \\
\text { болести } \\
\text { fully agree / потпуно се слажем } \\
\text { rather disagree / уопште се не слажем }\end{array}$ & $\begin{array}{l}25,9 \\
50,6\end{array}$ & $\begin{array}{l}20,8 \\
54,4\end{array}$ & $\begin{array}{l}12,2 \\
35,8\end{array}$ \\
\hline $\begin{array}{l}\text { Their settlement will disturb the eth- } \\
\text { nic balance/ Њихово досељавање ће } \\
\text { пореметити етничку равнотежу } \\
\text { fully agree / потпуно се слажем } \\
\text { rather disagree / уопште се не слажем }\end{array}$ & $\begin{array}{l}28,2 \\
47,8\end{array}$ & $\begin{array}{l}26,5 \\
41,3\end{array}$ & $\begin{array}{l}14,6 \\
26,9\end{array}$ \\
\hline
\end{tabular}


Table 3. What should the state provide for refugees and the degree of importance attached to basic values ${ }^{2}$ (in \%)/

Табела 3. Шта држава треба да обезбеди избеглицама и који је степен значаја који се придаје основним вредностима ${ }^{2}$ (y \%)

\begin{tabular}{|c|c|c|c|c|c|c|c|c|c|}
\hline & \multirow[t]{2}{*}{$\begin{array}{l}\text { National } \\
\text { sample / } \\
\text { Национални } \\
\text { узорак }\end{array}$} & \multicolumn{2}{|c|}{$\begin{array}{l}\text { Ethnic and } \\
\text { religious } \\
\text { tolerance / } \\
\text { Етничка } \\
\text { и верска } \\
\text { толеранција }\end{array}$} & \multicolumn{2}{|c|}{$\begin{array}{l}\text { Equality of } \\
\text { different } \\
\text { cultures / } \\
\text { Једнакост } \\
\text { различитих } \\
\text { култура }\end{array}$} & \multicolumn{2}{|c|}{$\begin{array}{l}\text { Solidarity/ } \\
\text { Солидарност }\end{array}$} & \multicolumn{2}{|c|}{$\begin{array}{l}\text { Equality } \\
\text { between } \\
\text { people / } \\
\text { Једнакост } \\
\text { међу } \\
\text { људима }\end{array}$} \\
\hline & & 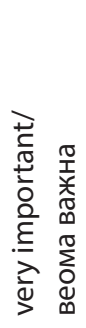 & 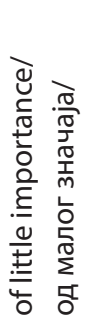 & 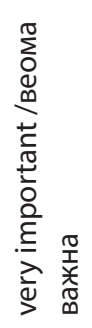 & 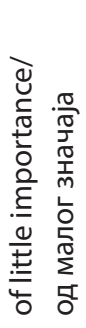 & 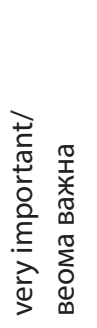 & 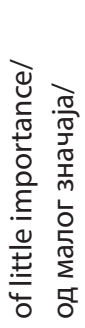 & 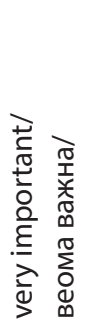 & 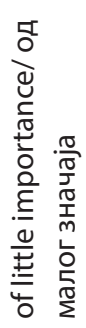 \\
\hline $\begin{array}{l}\text { Shelter/ } \\
\text { Смештај }\end{array}$ & 76,5 & 80,6 & 73,5 & 80,8 & 78,5 & 82,6 & 76,6 & 85,5 & 71,8 \\
\hline Food/ Храна & 76,3 & 80,1 & 73,9 & 82,4 & 76,4 & 83,6 & 75,3 & 84,8 & 73,6 \\
\hline $\begin{array}{l}\text { Healthcare/ } \\
\text { Здравствена } \\
\text { заштита }\end{array}$ & 79,9 & 81,1 & 86,4 & 83,4 & 85,0 & 83,1 & 84,4 & 86,2 & 83,6 \\
\hline $\begin{array}{l}\text { Education/ } \\
\text { Образовање }\end{array}$ & 39,1 & 58,3 & 23,5 & 49,7 & 24,1 & 59,2 & 18,2 & 46,0 & 29,4 \\
\hline $\begin{array}{l}\text { Language } \\
\text { courses/ } \\
\text { Курсеви } \\
\text { језика }\end{array}$ & 38,0 & 62,1 & 21,6 & 56,3 & 18,0 & 57,8 & 16,9 & 46,2 & 23,9 \\
\hline $\begin{array}{l}\text { Employment/ } \\
\text { Запослење }\end{array}$ & 23,6 & 43,7 & 11,7 & 36,3 & 9,8 & 45,0 & 7,8 & 29,4 & 13,8 \\
\hline
\end{tabular}

2 The comparison of variations in attitudes depending on the importance given to values is between the positions "very important" and "of little importance", as the extreme position "it doesn't matter at all" is held by a very small number of respondents and its use in search of relationships is not relevant.

2 Поређење варијација у ставовима у зависности од перцепције претњи дато је између ставова „веома важно” и „од малог значаја”, где екстремни став „уопште није важн” има веома мали број испитаника, па његова употреба у потрази за везама није релевантна. 
Table 4. Attitudes to spatial proximity to immigrants and perceptions of some threats(in \%)/

Табела 4. Ставови о просторној близини миграната и перцепције одређених претњи (y \%)

\begin{tabular}{|c|c|c|c|}
\hline & $\begin{array}{l}\text { Should live in } \\
\text { closed cen- } \\
\text { tres / Tреба } \\
\text { да живе у } \\
\text { затвореним } \\
\text { центрима }\end{array}$ & $\begin{array}{l}\text { Consent that ref- } \\
\text { ugees settle in } \\
\text { the community/ } \\
\text { neighbourhood } \\
\text { / Сагласност o } \\
\text { досељавању } \\
\text { избеглица у } \\
\text { заједницу или } \\
\text { суседство }\end{array}$ & $\begin{array}{l}\text { Consent to } \\
\text { have a refugee } \\
\text { accommoda- } \\
\text { tion centre in } \\
\text { the vicinity / } \\
\text { Сагласност } \\
\text { о центру } \\
\text { за смештај } \\
\text { избеглица у } \\
\text { близини }\end{array}$ \\
\hline $\begin{array}{l}\text { National sample/ Национални } \\
\text { узорак }\end{array}$ & 75,9 & 20,7 & 16,3 \\
\hline $\begin{array}{l}\text { Their subsistence imposes signif- } \\
\text { icant financial burden/ Њихово } \\
\text { издржавање намеће огроман } \\
\text { финансијски терет } \\
\text { fully agree/ потпуно се слажем } \\
\text { rather disagree/ уопште се не слажем }\end{array}$ & $\begin{array}{l}88,6 \\
25,0\end{array}$ & $\begin{array}{l}10,7 \\
43,3\end{array}$ & $\begin{array}{l}11,8 \\
32,7\end{array}$ \\
\hline $\begin{array}{l}\text { They take the jobs of the locals/ } \\
\text { Они одузимају послове локалном } \\
\text { становништву } \\
\text { fully agree/ потпуно се слажем } \\
\text { rather disagree/ уопште се не слажем }\end{array}$ & $\begin{array}{l}88,6 \\
71,7\end{array}$ & $\begin{array}{l}14,1 \\
26,5\end{array}$ & $\begin{array}{l}11,3 \\
18,5\end{array}$ \\
\hline $\begin{array}{l}\text { They pose a threat of terrorism/ Они } \\
\text { представљају терористичку претњу } \\
\text { fully agree/ потпуно се слажем } \\
\text { rather disagree/ уопште се не слажем }\end{array}$ & $\begin{array}{l}87,4 \\
65,7\end{array}$ & $\begin{array}{l}11,2 \\
36,1\end{array}$ & $\begin{array}{l}12,2 \\
18,7\end{array}$ \\
\hline $\begin{array}{l}\text { They commit crimes against the } \\
\text { locals/ Они врше кривична дела над } \\
\text { локалним становништвом } \\
\text { fully agree/ потпуно се слажем } \\
\text { rather disagree/ уопште се не слажем }\end{array}$ & $\begin{array}{l}92,7 \\
54,1\end{array}$ & $\begin{array}{c}6,4 \\
39,1\end{array}$ & $\begin{array}{c}5,9 \\
29,9\end{array}$ \\
\hline $\begin{array}{l}\text { They carry diseases/ Они преносе } \\
\text { болести } \\
\text { fully agree/ потпуно се слажем } \\
\text { rather disagree/ уопште се не слажем }\end{array}$ & $\begin{array}{l}87,6 \\
63,7\end{array}$ & $\begin{array}{l}10,3 \\
32,7\end{array}$ & $\begin{array}{l}12,9 \\
22,5\end{array}$ \\
\hline $\begin{array}{l}\text { Their settlement will disturb the eth- } \\
\text { nic balance/ Њихово досељавање ће } \\
\text { пореметити етничку равнотежу } \\
\text { fully agree/ потпуно се слажем } \\
\text { rather disagree/ уопште се не слажем }\end{array}$ & $\begin{array}{l}90,0 \\
63,5\end{array}$ & $\begin{array}{c}9,1 \\
30,7\end{array}$ & $\begin{array}{l}7,8 \\
29,0\end{array}$ \\
\hline
\end{tabular}


Table 5. Approval of actions in support of, or against, refugees and the importance attached to certain values(in \%) / Табела 5. Одобравање поступака у корист или против избеглица (у \%) и значај који се придаје одређеним вредностима

\begin{tabular}{|c|c|c|c|c|}
\hline & $\begin{array}{l}\text { Collection } \\
\text { donations for } \\
\text { immigrants / } \\
\text { Сакупљање } \\
\text { донација за } \\
\text { мигранте }\end{array}$ & $\begin{array}{l}\text { Voluntary } \\
\text { work to help } \\
\text { immigrants / } \\
\text { Добровољни } \\
\text { рад ради } \\
\text { помоћи } \\
\text { мигрантима }\end{array}$ & $\begin{array}{l}\text { Petitions } \\
\text { against the } \\
\text { acceptance of } \\
\text { immigrants } \\
\text { / Петиције } \\
\text { против } \\
\text { прихватања } \\
\text { миграната }\end{array}$ & $\begin{array}{l}\text { Peaceful action } \\
\text { against the } \\
\text { acceptance of } \\
\text { immigrants/ } \\
\text { Мирне акције } \\
\text { против } \\
\text { прихватања } \\
\text { миграната }\end{array}$ \\
\hline $\begin{array}{l}\text { National sample / } \\
\text { Национални узорак }\end{array}$ & 26,1 & 21,1 & 26,7 & 31,0 \\
\hline $\begin{array}{l}\text { Ethnic and religious tol- } \\
\text { erance/ Етничка и верска } \\
\text { толеранција } \\
\text { very important / веома } \\
\text { важна } \\
\text { of little importance / од } \\
\text { малог значаја }\end{array}$ & $\begin{array}{c}46,8 \\
6,8\end{array}$ & $\begin{array}{c}40,4 \\
6,8\end{array}$ & $\begin{array}{l}13,8 \\
38,3\end{array}$ & $\begin{array}{l}18,7 \\
40,7\end{array}$ \\
\hline $\begin{array}{l}\text { Freedom of movement / } \\
\text { Слобода кретања } \\
\text { very important / веома } \\
\text { важна } \\
\text { of little importance / од } \\
\text { малог значаја }\end{array}$ & $\begin{array}{l}36,7 \\
13,5\end{array}$ & $\begin{array}{l}31,6 \\
10,1\end{array}$ & $\begin{array}{l}24,9 \\
24,3\end{array}$ & $\begin{array}{l}28,0 \\
27,7\end{array}$ \\
\hline $\begin{array}{l}\text { Solidarity/ Солидарност } \\
\text { very important / веома } \\
\text { важна } \\
\text { of little importance / од } \\
\text { малог значаја }\end{array}$ & $\begin{array}{c}43,1 \\
9,8\end{array}$ & $\begin{array}{c}36,7 \\
8,4\end{array}$ & $\begin{array}{l}19,4 \\
37,7\end{array}$ & $\begin{array}{l}24,8 \\
39,9\end{array}$ \\
\hline $\begin{array}{l}\text { Equality of different } \\
\text { cultures/ Једнакост } \\
\text { различитих култура } \\
\text { very important / веома } \\
\text { важна } \\
\text { of little importance/ од } \\
\text { малог значаја }\end{array}$ & $\begin{array}{l}37,8 \\
12,8\end{array}$ & $\begin{array}{c}31,6 \\
9,4\end{array}$ & $\begin{array}{l}16,1 \\
33,6\end{array}$ & $\begin{array}{l}22,3 \\
37,3\end{array}$ \\
\hline $\begin{array}{l}\text { Equality between people/ } \\
\text { Једнакост међу људима } \\
\text { very important / веома } \\
\text { важна } \\
\text { of little importance / од } \\
\text { малог значаја }\end{array}$ & $\begin{array}{l}29,0 \\
21,1\end{array}$ & $\begin{array}{l}22,3 \\
20,2\end{array}$ & $\begin{array}{l}17,8 \\
34,9\end{array}$ & $\begin{array}{r}22,0 \\
39,4 \\
105\end{array}$ \\
\hline
\end{tabular}

